\title{
Organizational Citizenship Behavior and \\ Developmental Experiences: Do Role Definitions Moderate the Relationship?
}

\author{
Unnikammu Moideenkutty \\ Sultan Qaboos University
}

\begin{abstract}
Data from 136 supervisor-subordinate dyads indicated that Organizational Citizenship Behavior (OCB) was positively related to developmental experiences after controlling for In-Role Performance (IRP). Results also indicated that when supervisors had broad role definitions, the relationship between OCB and developmental experiences was non-significant. On the other hand, when supervisors had narrow role definitions, there was a significant positive relationship between OCB and developmental experiences reported by employees.
\end{abstract}

Key words: organizational citizenship behavior, developmental experiences, role definitions

\section{Introduction}

Recently there has been a dramatic increase in research on organizational citizenship behavior (OCB) (Podaskoff, MacKenzie, Paine, \& Bachrach, 2000) or behavior that contributes indirectly to the organization through the maintenance of the organization's social system (Organ, 1997). This increase can be attributed to the greater use of flatter and autonomous team-based structures in organizations and the consequent emphasis on individual initiative and cooperation (Lepine, Erez, \& Johnson, 2002).

Most of the early research on OCB focused on its antecedents. More recently, increasing attention has been paid to the consequences of OCB (Podaskoff, et al, 2000). Findings from this line of research indicate that OCB has important consequences for both the organization and individual employees (Podaskoff, et al, 2000).

At the organizational level, studies indicate that OCB is related to organizational effectiveness (Podsakoff, Ahearne, \& MacKenzie, 1997; Podsakoff \& MacKenzie, 1994; Walz \& Niehoff, 1996). At the individual level, OCB has been found to affect supervisory evaluations of employee performance (Podsakoff, MacKenzie, \& Hui, 1993), reward recommendations (Allen \& Rush, 1998; Kiker \& Motowidlo, 1999; Park \& Sims, 1989), and estimates of the dollar value of standard deviation difference in performance (Orr, Sackett, \& Mercer, 1989). In addition, a recent field quasiexperiment found that employees who perform higher levels of OCB are more likely to be promoted than employees who perform lower levels of OCB (Hui, Lam, \& Law, 2000). In summary, these studies indicate that the effect of OCB on personnel decisions of supervisors is at least as great as that of task performance (Podsakoff, et al, 2000). 
Podsakoff et al. (2000) recommend that future research should examine the impact of OCBs on other personnel decisions of supervisors, including those related to training. This study tests the relationship of OCB to developmental experiences of employees. Developmental experiences include, opportunities for training and development, challenging work assignments, and work assignments with greater responsibility (Wayne, Shore \& Liden, 1997). Though Allen and Rush (1998) included opportunities for professional development as an item in their measure of reward recommendations, the effect of OCB on the developmental experiences of subordinates have not been studied so far.

The willingness of supervisors to provide developmental experiences for their subordinates based on their OCB is likely to depend on whether they consider this behavior to be an expected part of the individual's job. An individual's interpretation of what constitutes the role obligations of a specific job can be called his or her role definition of that job (Morrison, 1994). This study also tests the moderating effect of supervisor's role definition of an employee's job on the relationship between OCB and developmental experiences.

It is important for employees to understand the consequences of engaging or not engaging in OCB. Since OCB is often considered to be discretionary, a clear understanding of the consequences will help employees to make more informed choices about engaging in OCB. It is also important for employees to know the circumstances under which supervisors value OCB. If the role definitions of supervisors and employees are different, what employees may consider as extra-role behavior may be viewed as in-role by supervisors and therefore as not meriting any special consideration.

\section{Literature Review}

Social exchange theory (Blau, 1964) is the theoretical framework on which most of the research on OCB is based (Konovsky \& Pugh, 1994; Organ, 1988). Social exchange theory suggests that social relationships (including employment relationships) can be classified into two types, social exchange relationships and economic exchange relationships. Social exchange relationships are relationships in which the mutual obligations of the parties are not formally specified. When one party to the relationship provides a resource to the other party, there is an expectation that a similar resource will be returned (Foa \& Foa, 1980), but the exact nature and timing of the return is discretionary. These relationships are characterized by feelings of personal obligation, gratitude, and trust. Such relationships encourage spontaneous and cooperative behaviors (like OCB) that go beyond formally specified obligations. Economic exchange relationships, on the other hand, are relationships in which the conditions of the exchange are clearly specified. In such relationships, the parties are unlikely to engage in spontaneous or cooperative behaviors that go beyond specifications. Organ (1990) suggests that individuals enter an organization presuming a social exchange relationship and are willing to engage in citizenship behaviors. They will continue to 
engage in citizenship behaviors until their treatment by the organization forces them to redefine the relationship as an economic exchange. Developmental experiences are consequences of OCB that could promote the belief that the relationship with the organization is a social exchange.

This view is supported by the results of experimental studies on the effects of OCB on performance evaluations and reward allocation decisions (Allen \& Rush, 1998; Kiker \& Motowidlo, 1999; Werner, 1994). In these studies, OCB (independent variable) was manipulated to study its effects on overall performance evaluations and reward allocation decisions. Manipulation of OCB had important influences on the dependent variables. These studies provide a stronger evidence of direction of causality than the cross-sectional field studies. Further, in all the above studies, OCB affected supervisory decisions after controlling for in-role performance. These studies clearly indicate that OCB influences performance evaluations and reward allocation decisions after controlling for task performance.

Based on the above discussion, it can be hypothesized that:

Hypothesis 1: OCB will be positively related to developmental experiences after controlling for in-role performance.

Research on role making (Graen, 1976) suggests that roles in organization are seldom fixed and that role perceptions evolve as employees and supervisors negotiate the scope of work activities. Similarly, work on psychological contracts (Rousseau, 1989) indicates that employees and employers have substantially different understandings about employment obligations. Finally, social information processing research (Salancik, \& Pfeffer, 1978) suggests that jobs are cognitive constructions created when employees and employers make sense of social and behavioral cues. Work roles are therefore likely to be socially constructed with only a subjective boundary between inrole and extra-role work behavior (Morrison, 1994). This makes what constitutes these two types of behaviors subject to multiple interpretations.

Morrison's (1994) empirical results indicated that employees and supervisors differed in that which each perceived to be in-role and extra-role behavior. Morrison also found that employees were more likely to engage in behaviors that they considered to be inrole rather than extra-role.

Tepper, Lockhart and Hoobler (2001) found that employees' role definitions moderated the relationship between fairness and OCB. The relationship was stronger when employees considered the behavior to be extra-role. Allen and Rush (1988) did not find a moderating effect for the supervisors' role definitions on the relationship of OCB to supervisors' liking for the employee and perceived organizational commitment. They did not test for the moderating effect of role definitions on the relationship between OCB and reward recommendations.

It seems likely that the breadth of the supervisors' role definitions will affect the supervisory evaluations of employee behavior. If a supervisor's role definition is broad 
and considers many citizenship behaviors to be an expected part of the employee's job, these behaviors are less likely to merit special attention. On the other hand, if the supervisor's role definition is narrow and considers many citizenship behaviors to be beyond what is expected from the employee, such behaviors are likely to lead to very positive evaluations and therefore to a greater willingness to provide developmental experiences for the employee.

Since OCB is generally helpful to the supervisor (MacKenzie, Podsakoff, \& Fetter, 1991), good citizens will be liked by supervisors regardless of whether they consider these behaviors to be an expected part of that individual's job. Similarly, supervisors may also attribute high organizational commitment to individuals who are good citizens. Hence, it is not surprising that Allen and Rush (1998) failed to find a moderating effect for role definitions in their study. However, when allocating rewards, supervisors will tend to search for distinguishing information (DeNisi, Cafferty, \& Meglino, 1984). When OCB is not an expected part of an employee's job, it will be seen as a distinguishing form of subordinate behavior and therefore merit consideration when making reward allocation decisions. Therefore, it is likely that the supervisor's role definition of the employee's job will moderate the relationship between OCB and developmental experiences. Hence, it can be hypothesized that:

Hypothesis 2: The relationship between OCB and developmental experiences will be moderated by the supervisor's role definition of the employee's job, such that, the relationship will be stronger when the supervisor's role definition is narrow.

\section{Methods}

\section{Sample and Data Collection}

The sample consisted of employed graduate and undergraduate business students from two universities in the northeastern part of United States and their supervisors or subordinates. Surveys were administered to the subjects during class with the permission of the instructor. Surveys consisted of two parts, the employee survey and the supervisor survey. One part was completed by the student and returned to the researcher. The other part was completed by the immediate supervisor of the student (when the student was the employee) or by the student's subordinate (when the student was the supervisor). The non-student respondents mailed the completed surveys directly to the researcher. Addressed and stamped envelopes were provided for this purpose. The two parts of the survey had a common serial number, which was used to match the employee and the supervisor parts of the survey.

Items measuring developmental experiences were included in the employee survey. Items measuring in-role performance, OCB and role definition were included in the supervisor survey. A total of 357 surveys were administered. The response rate was 43.98 percent, and 157, matched employee-supervisor surveys were returned. Unfortunately, missing values reduced the effective sample size for statistical analysis to 136 in some cases. 
Out of the 157 employee respondents, 49.68 percent were females, 38 percent were graduate students, and 7.05 percent were union members. Most of them were employed full-time (93.59 percent) and 29.49 percent had supervisory responsibilities. The average tenure was 4.503 years $(\underline{S D}=4.921)$. Almost 95 percent were between the ages of 20 and 49 years. The major industries represented in the sample were, healthcare (13.4 percent), banking/finance (14.6 percent), and other (48.4 percent). The major job categories represented in the sample were, professional (34.4 percent), office/clerical (15.3 percent), technical (12.1 percent), and management (12.1 percent).

Females constituted 46.11 percent of the supervisory sample. The average tenure of the supervisors was 6.994 years $(\underline{S D}=6.983)$. More than 80 percent reported their level of formal education as an undergraduate degree or graduate school. More than 90 percent were between 20 and 49 years of age.

\section{Measures}

In this section, the measures used in the study are described. These are in-role performance, organizational citizenship behavior, role definition and developmental experiences.

\section{$\underline{\text { In-Role Performance }}$}

In-role performance was measured with 4 items based on the scale developed by Williams and Anderson (1991). The items were, "fulfills the responsibilities specified in his/her job description," "performs the tasks that are expected as part of the job," "meets performance expectations," "adequately completes responsibilities." The responses ranged from "strongly disagree" to "strongly agree" (1-7). The reliability (Cronbach's alpha) of the scale was .962.

\section{Organizational Citizenship Behavior}

Organizational citizenship behavior was measured with 15 items taken from various OCB scales in the literature. The items and their sources are given in Appendix A. The items were chosen to represent supervisor directed OCB, co-workers directed OCB, and organization directed OCB (Barr \& Pawar, 1995; Moideenkutty, 2000). The reliability (Cornbach's alpha) of the scale was .899. The responses were "never true" to "always true"(1-5).

\section{Role Definition}

Role definition was measured with the slightly modified versions of the 15 items used to measure OCB. For example, items reflecting undesirable behavior (reverse coded items) were worded in the reverse. The wordings of the items were changed slightly to make them correspond to the response format. For example, "conserves and protects organization's property" was changed to "conserving and protecting organization's 
property." Supervisors were asked to indicate whether they considered each behavior to be an expected part of the employee's job or to be above and beyond what is expected for the employee's job. Morrison (1994) used a similar measure of role definition. A dichotomous response format rather than a continuous one was used because Morrison (1994) found that more valid responses were obtained in the former case. Job definition was computed by summing the number of behaviors that the supervisor indicated as being part of the employee's job and then dividing that sum by 15. The responses were scored $0-1$, with values closer to 1 indicating a broader job definition.

\section{Developmental Experiences}

In this study, developmental experiences were measured with 3 items with the highest factor loadings from the four-item scale of developmental experiences reported in Wayne, Shore, and Liden (1997). The wordings of the items were changed so that all of them could have the same response format i.e. "strongly disagree" to "strongly agree" (1-7). The items used in this study were, "My supervisor is usually willing to make a substantial investment in me by providing formal training and development opportunities, " "I am usually considered for additional challenging assignments," and "I am usually assigned to projects that would enable me to develop and strengthen new skills." The reliability (alpha) of this scale was 0.779 .

\section{$\underline{\text { Statistical Analysis }}$}

The first hypothesis was tested using multiple regression analysis. The second hypothesis was tested using hierarchical regression analysis (Aiken \& West, 1991). In the first step, the control and independent variable and the moderator variable were regressed on the dependent variable. In the second step, the interaction term was added. A significant change in the $\underline{R}^{2}$ in the second step indicates the presence of a moderator effect (Stone, 1986).

Once significant interactions are discovered, the next step is to probe the nature of the interaction. This was done by calculating regression coefficients for OCB at two levels of role definition. Calculations were made at one standard deviation above the mean of role definition, which represents a broad role definition and one standard deviation below the mean of role definition, which represents a narrow role definition (Cohen \& Cohen, 1983; Aiken \& West, 1991). Results

\section{Summary Statistics and Correlations}

The summary statistics and reliabilities of the major variables in the study are given in table 1. 


\section{$\underline{\text { Tests of Hypotheses }}$}

The first hypothesis proposed that OCB would have a positive relationship to developmental experiences. Developmental experiences were regressed on in-role performance and OCB. Table 2 shows the results of the regression analysis. OCB has a significant positive coefficient, indicating that developmental experiences are strongly related to OCB after controlling for in-role performance. Thus, $\mathrm{H} 1$ was strongly supported by the data.

The second hypothesis was tested by regressing developmental experiences first on inrole performance, OCB and role definition. The regression was rerun after adding the OCB-role definition cross product term. The results are shown in Table 3 . The interaction term is significant. The interaction term explains an additional 3.9 percent of the variance in developmental experiences (Adj. $R^{2}=0.033$ ). Results of the analysis of the interaction are shown in Table 4 . The interaction plot based on standardized betas is shown in Fig. 1. The slope for OCB is not significantly different from zero at role definition values one standard deviation above the mean. However, the slope is positive and significant for role definition values one standard deviation below the mean. Low role definition scores indicate narrow job definition. Thus, the results show that when the supervisor defined the job narrowly, OCB was related to developmental experiences. However, when the supervisor defined the job broadly, there was no effect of OCB on developmental experiences. These results provide support for $\mathrm{H} 2$. 
Table 1. Summary Statistics and Correlations

\begin{tabular}{|c|c|c|c|c|c|c|c|}
\hline Variable & $\mathrm{N}$ & Means & SD & IRP & OCB & $\begin{array}{l}\text { Role } \\
\text { Definition }\end{array}$ & $\begin{array}{l}\text { Developmental } \\
\text { Experiences }\end{array}$ \\
\hline 1. Task Performance & 179 & 23.922 & 4.834 & 0.962 & & & \\
\hline 2. OCB & 168 & 55.316 & 10.458 & $0.612^{* *}$ & 0.899 & & \\
\hline $\begin{array}{l}\text { 3. Role } \\
\text { Definition }\end{array}$ & 172 & 0.643 & 0.197 & -0.032 & 0.051 & 0.707 & \\
\hline $\begin{array}{l}\text { 4. Developmental } \\
\text { Experiences }\end{array}$ & 156 & 16.135 & 3.387 & $0.255^{\star *}$ & $0.316^{* *}$ & $0.249^{*}$ & 0.775 \\
\hline
\end{tabular}

Reliabilities are on the diagonal 
Table 2. Results of Regression Analysis for Developmental Experiences

\begin{tabular}{ll}
\hline $\begin{array}{l}\text { Independent } \\
\text { Variables }\end{array}$ & $\mathrm{B}$ \\
\hline Intercept & $10.029^{* *}$ \\
Task Performance & 0.081 \\
OCB & $0.075^{*}$ \\
\hline$\underline{R}^{\underline{2}}$ & 0.109 \\
Adj. ${ }^{\underline{2}}$ & 0.096 \\
$\mathrm{~F}$ & \\
$\mathrm{~N}$ & $8.583^{* *}$ \\
\hline Note: ${ }^{*} \underline{\mathrm{p}}<.05$ & 142 \\
\hline${ }^{* *} \underline{\mathrm{p}}<.01$
\end{tabular}


Table 3. Results of Moderated Regression Analysis for Role Definition: Independent Variable: OCB; Dependent

Variable-Developmental Experiences

\begin{tabular}{|c|c|c|c|}
\hline \multirow{2}{*}{$\begin{array}{l}\text { Independent } \\
\text { Variables }\end{array}$} & \multicolumn{2}{|l|}{ B } & \multirow[t]{2}{*}{$\underline{\Delta \mathrm{R}^{2}}$} \\
\hline & Without Interaction & With Interaction & \\
\hline Intercept & $8.197^{* *}$ & -1.942 & \\
\hline $\begin{array}{l}\text { Task } \\
\text { Performance }\end{array}$ & 0.091 & 0.092 & \\
\hline OCB & $0.068^{* *}$ & $0.244^{* *}$ & \\
\hline Job Definition & $3.172^{*}$ & $19.422^{* *}$ & \\
\hline Interaction & & $-0.282^{*}$ & \\
\hline$\underline{R}^{2}$ & 0.147 & 0.186 & 0.039 \\
\hline$\underline{\operatorname{Adj} . R^{2}}$ & 0.128 & 0.161 & 0.033 \\
\hline $\mathrm{F}$ & $7.677^{\star *}$ & $7.573^{* *}$ & \\
\hline$N$ & 136 & 136 & \\
\hline
\end{tabular}


Table 4. Results of Analysis of Interactions-OCB

One Standard Deviation One Standard Deviation

Above Mean of Role

Below Mean of Role

Definition

Definition

$\begin{array}{llc}\text { Slope } & 0.0346 & 0.145 \\ \mathrm{SE} & 0.034 & 0.032 \\ \mathrm{t} & 1.010 & 4.586^{* *}\end{array}$

Note: ${ }^{*} \underline{p}<.05 \quad{ }^{* *} \underline{p}<.01$

Fig. 1. Interaction Plot For Role Definition

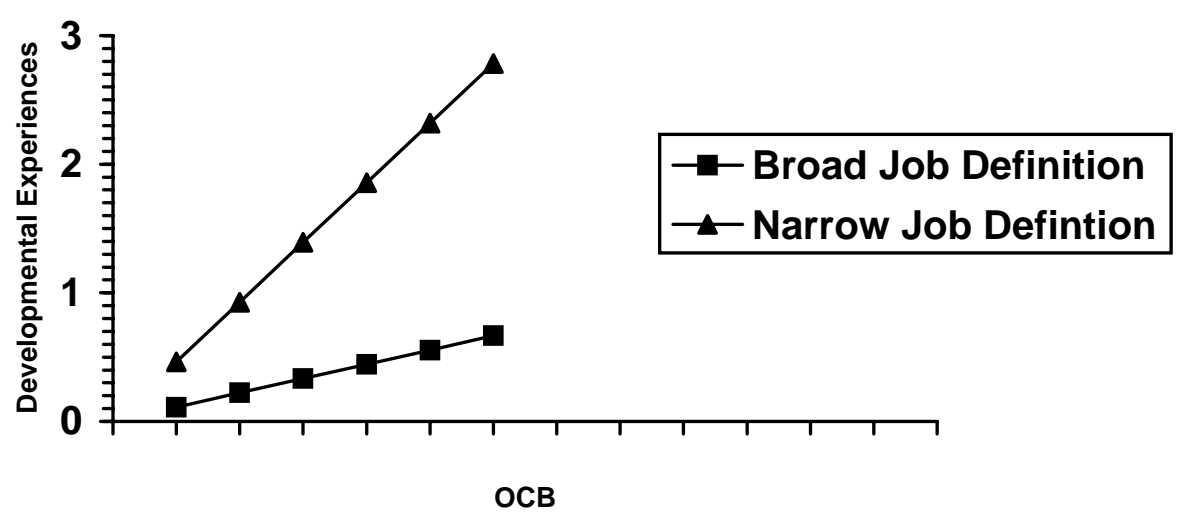




\section{Discussion}

As predicted, there was a positive relationship between OCB and developmental experiences after controlling for task performance. Also as predicted, supervisory job definitions moderated the relationship between OCB and developmental experiences. This relationship was significant only when the supervisor defined the job narrowly and not when the supervisor defined the job broadly.

The relationship between OCB and developmental experiences indicate that employees who engage in citizenship behaviors are more likely to receive outcomes that have long-term benefits for them. The effect of OCB on developmental experiences has not been tested so far. The findings of the present study contribute to this line of research by showing that citizenship behavior affects managers' decisions regarding allocation of developmental experiences.

The hypothesis proposing that the relationship between citizenship behaviors and developmental experiences would be moderated by supervisors' definition of the employee's job was supported. This indicates that when supervisors consider the behaviors defined here as OCB to be above and beyond the call of duty, it may influence supervisory decisions about providing long-term developmental opportunities for employees. On the other hand, when supervisors consider these behaviors to be an expected part of employee's job, they appear to lose their salience. However, it must be noted that when employees report developmental experiences, they are likely to report outcomes already received. Since the time that each employee worked under the supervisor is not known, it is possible that employees are reporting about developmental experiences that may not have been provided by their current supervisors. The current supervisors, however, reported the job definitions. Therefore, some caution is warranted while interpreting these results.

In summary, the study found that citizenship behaviors had a positive relationship to developmental experiences. These findings contribute to the research on the outcomes of OCB. The study also showed that the relationship between OCB and developmental experiences was moderated by supervisory job definitions. This is again an extension of the research on the outcomes of OCB. While considerable research has explored the relationship between OCB and its outcomes, little research has looked at the factors that affect this relationship. An example of the latter is the study by Allen and Rush (1998). This study identified liking and perceived organizational commitment as mediators of the relationship between OCB and supervisory evaluation and reward recommendations. However, contrary to their expectations, role definitions did not moderate the relationship between OCB and liking and perceived organizational commitment. Earlier, it was suggested that this might have been because OCB is generally helpful behavior, regardless of whether it is in-role or extra-role. However, it appears that because supervisors look for distinctiveness information while evaluating employees and making reward allocation decisions (DeNisi, Cafferty, \& Meglino, 1984), role definitions tend to moderate the relationship between OCB and these decisions. 


\section{Strengths and Limitations of the Study}

This study has a number of strengths that increases the internal and external validity of the results. First, the independent and dependent variables were measured from different sources. Task behavior, OCB, and job definitions were measured from supervisors. Employees reported developmental experiences. This method effectively addresses a frequent alternate explanation for correlational studies, namely, common method variance (Podsakoff \& Organ, 1986).

Second, the data was collected from a very diverse sample. A number of different organizations, occupations, and levels were represented in the sample. The sample consisted of union and non-union and part-time and full-time employees. This increases the generalizability of the results of the study. A third strength of the study was that the sample consisted of actual supervisor-employee dyads.

The primary limitation of the study is that it is correlational. Therefore, no causal claims can be made for the relationship between the independent and dependent variables. Another limitation of the study is that not all individuals who were given the survey responded to it. Responding to the survey can be considered as a citizenship behavior, and it is possible that the employee sample is biased in favor of good citizens.

\section{Avenues for Future Research}

There is limited research on the factors that affect the relationship between OCB and its outcomes for individuals (Allen \& Rush, 1998). Apart from role definitions, there could be other moderators of the relationship between OCB and individual outcomes. One possible moderator is impression management. Allen and Rush (1998) found that attribution of altruistic motives fully mediated the relationship between OCB and performance evaluations and partially mediated the relationship between $O C B$ and reward recommendations. Future research could explore the role of impression management in the relationship between OCB and individual outcomes.

\section{$\underline{\text { Implications for Practice }}$}

The findings of this study provide a number of implications for practice. The significant relationship between OCB and developmental experiences indicates that employees who want to develop their skills and get ahead in the organization on a long-term basis must engage in these behaviors. The finding that this effect was stronger when supervisory job definitions were narrow indicates that employees need to be made aware of the behaviors that are valued by powers that be, even if they are not considered as an expected part of the job. 


\section{Appendix A}

$\underline{\text { OCB Scale Items }}$

Item

Source

1. Defends the organization when other

Moorman \& Blakely, 1992 employees criticize it

Moorman \& Blakely, 1992

2. Shows pride when representing the organization in public

3. Actively promotes organization's products and services to potential users

4. Conserves and protects organization's property

5. "Keeps up" with developments in the organization

Moorman \& Blakely, 1992

Williams \& Anderson, 1991

6. Attends functions that are not required but that help the organization's image

7. Always goes out of the way to make newer employees welcome in the work group

8. Shows genuine concern and courtesy toward co-workers, even under the most trying business or personal situations

9. Frequently adjusts his or her work schedule to accommodate other employees' requests

for time off

10. Avoids extra duties and responsibilities at work

Van Dyne, Graham, \& Dienesch, 1994

11. Does work beyond what is required

Van Dyne, Graham, \&

Dienesch, 1994

12. Volunteers for overtime work when

Van Dyne, Graham, \& needed

Dienesch, 1994

MacKenzie, Podsakoff, \&

MacKenzie, Podsakoff, \& Fetter, 1991

Moorman \& Blakely, 1992

Moorman \& Blakely, 1992

Moorman \& Blakely, 1992 
13. Assists me with my work even when not asked

14. Adheres to informal rules devised to maintain order

15. Does not complain about insignificant things at work
Williams \& Anderson, 1991

Williams \& Anderson, 1991

Williams \& Anderson, 1991

\section{References}

Aiken, L. S., \& West, S. G. (1991). Multiple regression: Testing and interpreting interactions. Newbury Park, CA: Sage.

Allen, T. D. \& Rush, M. C. (1998). The effect of organizational citizenship behavior on performance judgments: A field study and a laboratory experiment. Journal of Applied Psychology, 83, 247-260.

Barr, S. H. \& Pawar, B. S. (1995). Organizational citizenship behavior: Domain specification for three middle range theories. Paper presented at annual meeting of Academy of Management, Vancouver, Canada.

Blau, P.M. (1964). Exchange and power in social life. New York: John Wiley \& Sons.

Cohen, J., \& Cohen, P. (1983). Applied multiple regression/correlation analysis for the behavioral sciences $\left(2^{\text {nd }}\right.$ ed.). Hillsdale, NJ: Lawrence Earlbaum Associates.

DeNisi, A. S., Cafferty, T. P., \& Meglino, B. M. (1984). A cognitive view of performance appraisal process: A model and research propositions. Organizational Behavior and Human Performance, 33, 360-396.

Foa, U. G., \& Foa, E. B. (1980). Resource theory: Interpersonal behavior as exchange. In K. S. Gergen, M. S. Greenberg, \& R. H. Willis (Eds.), Social exchange: Advances in theory and research (pp. 77-94). New York: Plenum Press.

Graen, G. (1976). Role making processes within complex organization. In M. D. Dunnette (Ed.), Handbook of industrial and organizational psychology (pp. 1201-1245). Chicago: Rand McNally.

Hui, C., Lam, S. S. K., \& Law, K. K. S. (2000). Instrumental values of organizational citizenship behavior for promotion: A field quasi-experiment. Journal of Applied Psychology, 85(5), 822-828. 
Kiker, D. S. \& Motowidlo, S. J. (1999). Main and interaction effects of task and contextual performance on supervisory reward decisions. Journal of Applied Psychology, 84, 602-609.

Konovsky, M. A., \& Pugh, S. D. (1994). Citizenship behavior and social exchange. Academy of Management Journal, 37, 656-669.

LePine, J. A., Erez, A., \& Johnson, D. E. (2002). The nature and dimensionality of organizational citizenship behavior: A critical review and meta-analysis. Journal of Applies Psychology, 87(1), 52-65.

MacKenzie, S. B., Podsakoff, P. M., \& Fetter, R. (1991). Organizational citizenship behavior and objective productivity as determinants of managerial evaluations of salespersons' performance. Organizational Behavior and Human Decision Processes, 50, 123-150.

Moideenkutty, U. (2000). Correlates and outcomes of organizational citizenship behavior directed toward the organization, the supervisor, and co-workers: A social exchange perspective. Unpublished doctoral dissertation, Temple University, Philadelphia.

Moorman, R. H. \& Blakely, G. L. (1992). A preliminary report on a new measure of organizational citizenship behavior. Paper presented at the annual meeting of the Southern Management Association, New Orleans, LA.

Morrison, E. W. (1994). Role definitions and organizational citizenship behavior: The importance of the employee's perspective. Academy of Management Journal, 37, 1543-1567.

Organ, D. W. (1988). Organizational citizenship behavior: The good soldier syndrome. Lexington, MA: Lexington Books.

Organ, D. W. (1990). Motivational basis of organizational citizenship behavior. In L.L. Cummings \& B. M. Staw (Eds.), Research in organizational behavior (Vol. 12, pp. 4372.). Greenwich, CT: Jai Press.

Organ, D. W. (1997). Organizational citizenship behavior: It's construct clean-up time. Human Performance, 10, 85-97.

Orr, J. M., Sackett, P. R., \& Mercer, M. (1989). The role of prescribed and nonprescribed behavior in estimating the dollar value of performance. Journal of Applied Psychology, 74, 34-40.

Park, O. S., \& Sims, H. P., Jr. (1989). How subordinate prosocial behavior influences performance ratings. Paper presented at the National Academy of Management Meeting, Washington, DC. 
Podsakoff, P. M., Ahearne, M., \& MacKenzie, S. B. (1997). Organizational citizenship behavior and the quantity and quality of work group performance. Journal of Applied Psychology, 82, 262-270.

Podsakoff, P. M. \& MacKenzie, S. B. (1994). Organizational citizenship behavior and sales unit effectiveness. Journal of Marketing Research, 3 (1), 351-363.

Podsakoff, P. M., Mackenzie, S. B., \& Hui, C. (1993). Organizational citizenship behaviors and managerial evaluations of employee performance: A review and suggestions for future research. In G. Ferris (Ed.), Research in Personnel and Human Resources Management (Vol. 11, pp. 1-40). Greenwich, CT: Jai Press.

Podsakoff, P. M., MacKenzie, S. B., Paine, J. B., \& Bachrach, D. G. (2000). Organizational citizenship behaviors: A critical review of the theoretical and empirical literature and suggestions for future research. Journal of Management, 26 (3), 513-563.

Podsakoff, P. M. \& Organ, D. W. (1986). Self-reports in organizational research: Problems and prospects. Journal of Management, 12, 531-544.

Rousseau, D. M. (1989). Psychological and implied contracts in organizations. Employee Responsibilities and Rights Journal, 2, 121-139.

Salancik, G. R., \& Pfeffer, J. (1978). A social information processing approach to job attitudes and task design. Administrative Science Quarterly, 223, 224-253.

Stone, E. F. (1986). Research methods in industrial and organizational psychology: Selected issues and trends. In C. L. Cooper \& I. Robertson (Eds.), International review of industrial and organizational psychology (pp. 305-334). London: Wiley.

Tepper, B. J., Lockhart, D., \& Hoobler, J. (2001). Justice, citizenship, and role definition effects. Journal of Applied Psychology, 86 (4), 789-796.

Van Dyne, L., Graham, J. W., \& Dienesch, R. M. (1994). Organizational citizenship behavior: Construct redefinition, measurement, and validation. Academy of Management Journal, 37, 765-802.

Walz, S. M. \& Niehoff, B. P. (1996). Organizational citizenship behaviors and their effect on organizational effectiveness in limited-menu restaurants. In J. B. Keys \& L. N. Dosier (Eds.), Academy of Management Best Papers Proceedings, 307-311.

Wayne, S. J., Shore, L. M. \& Liden, R. L. (1997). Perceived organizational support and leader-member exchange: A social exchange perspective. Academy of Management Journal, 10, 82-111. 
Werner, J. M. (1994). Dimensions that make a difference: Examining the impact of inrole and extra-role behaviors on supervisory ratings. Journal of Applied Psychology, 79, 98-107.

Williams, L. J., \& Anderson, S. E. (1991). Job satisfaction and organizational commitment as predictors of organizational citizenship and in-role behaviors. Journal of Management, 17, 601-617. 